\title{
Między ładem a chaosem: przygoda marszałka de Bassompierre w ujęciu Goethego i Hofmannsthala
}

\author{
DOI: http://dx.doi.org/10.12775/LC.2015.021
}

Streszczeni e. Przedmiotem artykułu jest porównanie sposobu literackiej realizacji tego samego tematu przez Goethego i Hofmannsthala w opowieści nawiązującej do wspomnień francuskiego arystokraty François de Bassompierre’a, żyjącego na przełomie XVI i XVII wieku. Chodzi o krótkotrwały, tajemniczo przerwany romans arystokraty z piękną kobietą niższego stanu. Johann Wolfgang Goethe, obserwując z niepokojem rozwój wypadków podczas Rewolucji Francuskiej oraz będąc naocznym świadkiem wojen napoleońskich, sięga do wspomnień Bassompierre’a na potrzeby swego wzorowanego na Dekameronie cyklu Gawędy uchodźców niemieckich, którego ogólna wymowa jest pochwałą idei ładu i powściągliwości. Hofmannsthal - jeden z czołowych przedstawicieli wiedeńskiej moderny - posługuje się tekstem Goethego, tworząc rodzaj palimpsestu; wypełnia przy tym uściślającą treścią wiele miejsc pierwotnie niedookreślonych. Przede wszystkim jednak zmienia narracyjne otoczenie opowieści: pozbawia ją (dydaktycznego) kontekstu, w jaki wyposażył ją jego poprzednik. W swojej wersji historii podkreśla takie elementy, jak niewyrażalność odczuć i celebrowanie doznań zmysłowych, dając wyraz swej estetyzującej wizji świata i tworząc tym samym utwór $\mathrm{w}$ znacznym stopniu polemiczny w stosunku do wersji Goethego.

S low a k l u c zow e : Johann Wolfgang Goethe; Hugo von Hofmannsthal; Bassompierre; narracja; dydaktyzm; estetyzm.

Abstract. Between order and chaos: Marshal de Bassompierre's adventure according to Goethe and to Hofmannsthal. The article discusses two ways of presenting the same theme:

* Autorka jest germanistką, absolwentką Uniwersytetu Warszawskiego, adiunktem w Katedrze Filologii Germańskiej Uniwersytetu Mikołaja Kopernika, prowadzi wykłady i seminaria z historii literatury niemieckiej, translatoryki i komparatystyki. Autorka monografii Ślad Abrahama. Zarys niemieckiej recepcji dzieła Kierkegaarda na przełomie XIX i XX wieku, Toruń 2001 oraz Słabość i bunt. O twórczości Franza Kafki w świetle Gombrowiczowskiej koncepcji "niedojrzałości", Toruń 2005, a także artykułów poświęconych twórczości takich autorów, jak Robert Musil, Franz Kafka, Heinrich von Kleist. Zajmuje się także przekładem. E-mail: klentak@umk.pl. 
Johann Wolfgang von Goethe's and Hugo von Hofmannsthal's reference to the recollections of the French aristocrat François de Bassompierre who lived at the turn of the $16^{\text {th }}$ and $17^{\text {th }}$ centuries. In his memoirs, Bassompierre describes an affair with a beautiful lower-class woman. Goethe, who anxiously watched the course of events during the French Revolution and was an eyewitness of the Napoleonic wars, includes his version of Bassompierre's "adventure" in the cycle modeled on Decameron, entitled Unterhaltungen deutscher Ausgewanderten. The work is mostly a praise of the idea of order and self-restraint. Using Goethe's text, Hofmannsthal - one of the leading representatives of Vienna modernism - creates a kind of palimpsest and deprives the story of its didactic context. Focusing in his version on aestheticism, Hofmannsthal emphasizes inexpressibility of sensations and celebration of sensuous experiences. As a result, he creates a polemic version of Goethe's work.

Key words : Johann Wolfgang Goethe; Hugo von Hofmannsthal; Bassompierre; narration; didacticism; aestheticism.

arszałek François de Bassompierre, francuski arystokrata, dyplomata i bon vivant żyjący na przełomie XVI i XVII wieku, jest autorem wspomnień, których fragment - relacjonujący jego przelotny romans z kobietą niższego stanu w Paryżu zagrożonym zarazą zainspirował dwie wybitne, ale różne osobowości artystyczne: Johanna Wolfganga Goethego i Hugona von Hofmannsthala. Powstały dwa utwory, znane jako Die schöne Krämerin (Piękna kramarka) Goethego ${ }^{1}$ oraz Das Erlebnis des Marschalls von Bassompierre (Przygoda marszatka de Bassompierre) Hofmannsthala. W ujęciu Goethego opowiadanie o marszałku Bassompierre i pięknej kramarce nie jest, jak u Hofmannsthala, samodzielnym utworem², lecz stanowi - obok pięciu innych krótszych i dłuższych historii otoczonych narracyjną ramą - część cyklu Gawędy uchodźców niemieckich ${ }^{3}$. Zasadnicze elementy akcji i narracji (narratorem jest w obu przypadkach Bassompierre) układają się u obu autorów w podobny sposób, dostarczając wyśmienitej okazji do porównań, z której literaturoznawstwo germanistyczne niejednokrotnie już zresztą korzystało ${ }^{4}$. W niniejszym szkicu chciałabym zwrócić

${ }^{1}$ W odniesieniu do tekstu Goethego funkcjonują w zasadzie zamiennie oba tytuły: Die schöne Krämerin i Das Erlebnis des Marschalls von Bassompierre, a w tzw. hamburskim wydaniu jego dzieł jest to Bassompierres Geschichte von der schönen Krämerin (Bassompierre'a historia o pięknej kramarce).

2 Przygoda marszałka de Bassompierre ukazała się po raz pierwszy drukiem w Wiedniu w roku 1900 w czasopiśmie „Die Zeit”, następnie w roku 1905 w wydaniu książkowym wraz z innymi tekstami w zbiorku Das Märchen der 672. Nacht und andere Erzählungen (o czym będzie jeszcze mowa); po polsku Przygoda marszałka de Bassompierre ukazała się w tłumaczeniu I. Wieniewskiej w roku 1919 we Lwowie razem z Baśnia 672. nocy, Powieścia o jeźdźcu i Listem; to wydanie dalej cytowane jest jako PMB z podaniem numeru strony.

3 J.W. von Goethe, Unterhaltungen deutscher Ausgewanderten, [w:] idem, Werke. Hamburger Ausgabe, t. 6: Romane und Novellen I, München 1981, s. 125-241, dalej cytowane jako UdA z podaniem numeru strony. Utwór ukazał się po raz pierwszy w czasopismie redagowanym przez Fryderyka Schillera „Die Horen“ w roku 1795, po polsku - fragmenty w przekładzie Wacława Berenta w roku 1924.

${ }^{4}$ W. Kraft, Das Erlebnis des Marschalls von Bassompierre, [w:] Hugo von Hofmannsthal, red. S. Bauer, Darmstadt 1968, s. 254-273, por. także L. Kovács, Grenzüberschreitungen: Goethes Bassompierre-Novelle, http://epa. oszk.hu/02100/02137/00018/pdf/EPA02137_ISSN_1219-543X_tomus_14_fas_3_2009_ger_161-166.pdf (dostęp: 21.11.2012). W drobiazgowej analizie porównawczej Kraft przytacza tekst Hofmannsthala niemal w całości; już wówczas sprzeciwia się też dominującej i później opinii, że Hofmannsthal jedynie silniej niż Goethe akcentuje psychologiczne motywacje postaci. Według Krafta Historia marszałka Bassompierre posłużyła Hofmannsthalowi przede wszystkim do doskonalenia warsztatu literackiego (s. 273). W odróżnieniu od tych przedstawień więcej miejsca i uwagi poświęcam konsekwencjom dla wymowy utworu płynącym z kontekstu (lub jego braku). 
uwagę na mniej uwzględnianą w znanych mi analizach rolę otoczenia narracyjnego obu opowieści, które w znacznej mierze przesądza o wymowie i przesłaniu pozornie tej samej przygody.

Najpierw - jako bardziej zwięzłej - przyjrzyjmy się wersji Goethego. Historia rozgrywa się w Paryżu u schyłku XVI wieku. Bassompierre bywa tu regularnie i przejeżdżając obok kramów nad Sekwaną, zwykle mija sklepik z szyldem przedstawiającym dwa anioły, a śliczna młoda kramarka zawsze pozdrawia go w wyszukany sposób. Powtarza się to w ciągu kilku miesięcy wielokrotnie, wreszcie Bassompierre proponuje kobiecie spotkanie, na co ta godzi się z nieukrywaną radością. W mieście szerzą się właśnie przypadki zarazy, toteż służący marszałka doradza zachowanie ostrożności ${ }^{5}$ Po wspólnie spędzonej nocy, kobieta proponuje następną schadzkę za dwa dni, jednak gdzie indziej, bo przebywanie dłużej w miejscu będącym de facto domem publicznym rani jej godność. Zaklina się, że Bassompierre jest jedynym, prócz jej męża, mężczyzną w jej życiu - „obym nędzną śmiercią umarła, jeśli należałam kiedykolwiek do kogo, oprócz do mego męża i do ciebie” (PMB 83). Zauroczony jej wyjątkowym wdziękiem i podniecony niezwykłością całej sytuacji Bassompierre zaniedbuje swoje obowiązki, niecierpliwie wyczekując wyznaczonego wieczoru. Gdy wreszcie trafia pod wskazany adres, zastaje dom rozświetlony od wewnątrz płomieniami, a w środku - kilku grabarzy, palących posłania w izbie; widzi, że na stole spoczywają dwa nagie ciała. Przerażony ucieka. Po powrocie do domu wypija znaczną ilość alkoholu, co ma go uchronić przed zarazą. Nie rozchorowuje się zresztą. Nigdy więcej nie udaje mu się spotkać pięknej kramarki, ani uzyskać jakiejkolwiek wiadomości o niej. Niezwykłe zdarzenie pozostaje na zawsze zagadką, ale wspomnienie fascynującej nieznajomej nie opuszcza go mimo upływu lat.

Niejasny finał przygody budzi różnorakie skojarzenia i pytania; niektóre padają już w tekście Gawęd z ust zaintrygowanych słuchaczy. Co się stało z piękną nieznajomą? Czy gdyby żyła, nie uczyniłaby wszystkiego, co w jej mocy, aby spotkać się z kochankiem? (UdA 165) Czy to jej ciało (i może ciało jej męża, a może innego kochanka) ujrzał Bassompierre w feralnym domu? Czy mąż, dowiedziawszy się o zdradzie, zabił ją z zazdrości? Czy jeśli przyczyną śmierci kobiety była zaraza, była chora już podczas schadzki z Bassompierre’em i czy zdawała sobie $\mathrm{z}$ tego sprawę? Czy może spadła na nią - w istocie kobietę rozpustną i wiarołomną - jej własna klątwa, nieroztropnie wypowiedziana wobec kolejnego kochanka? Jeśli chcemy trzymać się dostępnych nam faktów, skazani jesteśmy na niepewność i brak odpowiedzi na podstawowe pytania: nie wiadomo przecież nawet, jakiej płci były osoby, których zwłoki leżały w izbie. Tym bardziej jednak cała sytuacja nie daje nam spokoju i niejako domaga się interpretacji. Efekt ten w znacznej mierze wynika z zastosowanej w opowiadaniu formy narracji. Narrator pierwszoosobowy - a z takim mamy tu do czynienia - z natury rzeczy ma ograniczony wgląd w sytuację wobec niego zewnętrzną. Nie jest wszechwiedzącym bytem stojącym ponad fabułą, lecz postacią $\mathrm{w}$ fabułę uwikłaną i mimo (a może właśnie z powodu) bliskich koneksji z żywym człowiekiem o nazwisku Bassompierre musi pogodzić się ze swoją bardzo ograniczoną wiedzą. Ale czytelnik, ujrzawszy

\footnotetext{
${ }^{5}$ Intymny charakter spotkania jest w obu tekstach od początku określony z zaskakującą otwartością: u Goethego kramarka gotowa jest spotkać się z Bassompierre'em tylko pod tym warunkiem, że spędzą noc w jednym łożu (unter einer Decke), w obu tekstach zapobiegliwy służący natychmiast udziela marszałkowi praktycznych rad co do użycia własnej pościeli i materaców.
} 
tylko te wycinki świata przedstawionego, które są dostępne bezpośredniemu doświadczeniu Bassompierre'a, nie może się tym zadowolić. Chęć zrozumienia, o co naprawdę w tym wszystkim chodzi, jest zbyt silna, by poprzestać na akceptacji samych tylko skąpych faktów. Staramy się więc walczyć o zrozumienie: połączyć ze sobą elementy jawiące się Bassompierre'owi jako rozproszone i niespójne oraz mimo wszystko - nawet niejako ponad głową zdezorientowanego protagonisty i narratora w jednej osobie - wysnuć z nich (ukryty) sens. Tego sensu spodziewamy się bowiem po autorze. Nie bez przyczyny, bo o ile pierwszoosobowemu narratorowi świat utworu jedynie się jawi, to przez autora utworu jest on przecież ukazywany. Naiwne pytanie: „co autor miał na myśli?” jest w sumie tylko nie najszczęśliwszą wersją uprawnionego pytania o sens i cel utworu: co autor chciał nam powiedzieć, konstruując swój tekst w taki, a nie inny sposób? Wracając do postawionych wcześniej pytań o zniknięcie pięknej nieznajomej i koszmarną scenę w izbie, zdajemy sobie sprawę, że całkowite rozwikłanie zagadki jest niemożliwe, ale można starać się odczytać i zestawić ze sobą rozproszone w opowieści sygnały, zwracając uwagę na ich - określone przecież - znaczenie.

Elementem, który w tekście o tak szczupłej objętości ${ }^{6}$, a przy tym tak pełnym niedomówień, rzuca się w oczy, jest powracający motyw parzystości: dwa różne miejsca schadzki, dwa korytarze w domu wskazanym jako miejsce drugiego spotkania, z których jeden ma jakoby zaprowadzić mężczyznę w ramiona ukochanej, dwaj mężczyźni w jej życiu i wreszcie dwa nagie ciała spoczywające w izbie. I do tego para aniołów w szyldzie nad kramem z początku tekstu - opiekuńczych duchów, które, zdawałoby się, będą czuwać nad kochankami. Para ta w finale ustępuje jednak miejsca pozbawionym jakiejkolwiek magii, namacalnym zwłokom; może więc raczej antycypuje dalsze wypadki i zapowiada śmierć? Pojawiająca się tu tak często podwójność może być rozumiana z jednej strony jako atrybut miłości, gdyż dotyczy pary kochanków. Z drugiej strony aluzyjnie nawiązuje jednak i do dwuznaczności, jaką nacechowana jest przygoda marszałka z mężatką. Dwoistość sama w sobie jest niejednoznaczna. Można zatem dojść do wniosku, że tekst dobitnie akcentuje dwoistość jako taką, i to właśnie wywołuje dezorientację i odczucie, że to, co nam się jawi, nie jest być może tym, za co je bierzemy. Wątpliwość ta rodzi podejrzenie, że tkwi w tym wszystkim jakiś fałsz, a pod (ponętną?) powłoką kryje się coś zgoła innego. Szok Bassompierre’a na widok wnętrza izby jest przecież tym większy, że mężczyzna zjawia się tu podniecony i rozgorączkowany w oczekiwaniu czegoś zupełnie innego: zaplanowanej schadzki, w przeczuciu czekających go pod tym dachem rozkoszy. Tymczasem staje jak gdyby na progu piekła: płonące sienniki i nagie ciała przedstawiają widok iście infernalny. Ogień namiętności zostaje raptem skonfrontowany z - bez mała karzącym - ogniem wypalającym siedlisko zarazy. Sam Bassompierre stara się zatrzeć ślady owej zgrozy: woli pamiętać przyjemność, jakiej zaznał w ramionach nieznajomej, ale zamykające jego relację wyznanie, że żadna inna nie dorównała pięknej kramarce, przydaje jej postaci tym bardziej demonicznej aury. W oczach wrażliwego odbiorcy paradoksalnie na pierwszy plan wysuwa się nie obraz uroczej dziewczyny, ale przerażającej niespodzianki, która w niepojęty sposób zajęła jej miejsce ${ }^{7}$ W opowieści niezatarty pozostaje obraz szokującego rozdźwięku między oczekiwaniami a stanem faktycznym zastanym u progu alkowy.

\footnotetext{
${ }^{6}$ W cytowanym wydaniu (formatu A6) zajmuje on ledwie 18 stron.

7 Tak też reaguje na opowieść jedna z postaci Gawęd; podczas gdy inni zastanawiają się nad rozwikłaniem zagadki, wrażliwa Luiza uznaje opowieść za jedno wielkie okropieństwo (UdA, 165). Warto nadmienić, że wią-
} 


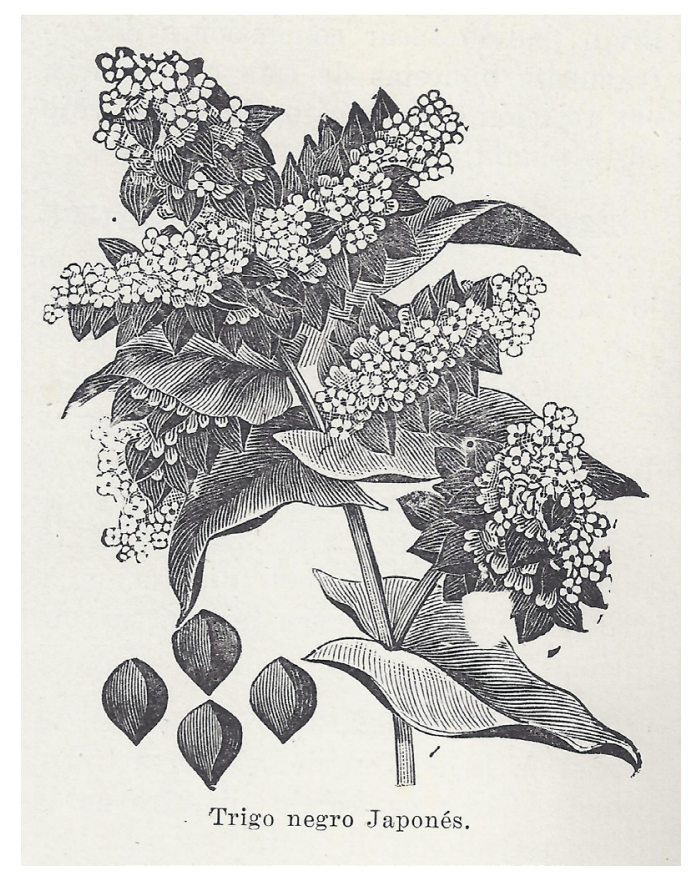

A jak wygląda ta opowieść w wersji Hofmannsthala? Hugo von Hofmannsthal, zaliczający zresztą Goethego do grona swoich wielkich przewodników duchowych i przyjaciól ${ }^{8}$, posługuje się jego tekstem, tworząc rodzaj palimpsestu: przejmuje całe fragmenty, niekiedy sekwencje zdań z wersji wcześniejszej, nieznacznie je modyfikując, ale całość istotnie rozszerza. W obrębie akcji dopowiedzenia i innowacje dotyczą na przykład pory roku: konkretyzując ją jako zimę, Hofmannsthal uzyskuje dodatkowy efekt kontrastu między lodowatym zewnętrzem a ogniem kominka - a także „ogniem” namiętności. Na płaszczyźnie opisu i środków wyrazu znacznie większą rolę odgrywa epizod wspólnej nocy. U Goethego zamyka się on w jednym zdaniu, natomiast $\mathrm{u}$ Hofmannsthala, operującego symbolami płomienia, owocu', ciemności i światła, przelotny romans urasta do rangi jedynego w swoim rodzaju miłosnego misterium, odprawianego $\mathrm{w}$ innym, przeobrażonym świecie - poza ludzkim językiem i poza granicą tego, co wyrażalne:

Potem znów zdało mi się, jakby chciała przemówić, lecz drżące od pocałunku wargi nie zdobyły się na żaden wyraz, a ze zdławionego gardła wyszło tylko tłumione łkanie. [PMB 78]

[...] gardło jej zadygotało, coś w niej wezbrało docierając aż do warg. Nie wyszło z nich ani słowem, ani westchnieniem, ni pocałunkiem, jeno czymś, co niezrodzone, podobne było do tego trojga. [PMB 81]

żąca się z podwójnością idea „sympatycznego związku między przedmiotami” jest również tematem rozmowy w opowieści ramowej tuż przed prezentacją historii Bassompierre'a.

${ }^{8}$ Por. D. Szcześniak, Z miłości do słowa (Hugo von Hofmannsthal , „Księga przyjaciół”), [w:] Arcydzieła literatury niemieckojęzycznej. Szkice, komentarze, interpretacje, red. E. Białek i G. Kowal, Wrocław 2011, s. 46.

9 Por. W. Kraft, op. cit. s. 261. Autor podkreśla symboliczną wymowę owych przedmiotów za Waltherem Brechtem, jednym z największych znawców twórczości Hofmannsthala, któremu pisarz osobiście przekazał notatki do swojej poetyckiej autobiografii Ad me ipsum, wydanej pośmiertnie (Hofmannsthals 'Ad me ipsum' und seine Bedeutung, Frankfurt am Main 1930). 
Zmysłowo zintensyfikowana narracja Hofmannsthala unaocznia więc granice, do których powściągliwa narracja Goethego w ogóle się nie zbliża.

Zupełnie nowym elementem jest wprowadzenie do opowieści rozbudowanego wątku postaci męża nieznajomej. Tu, inaczej niż w wersji Goethego, dłużący się czas oczekiwania na powtórne spotkanie Bassompierre stara się skrócić, krążąc w okolicy kramu przy moście; marzy, by „zobaczyć [...] bogdankę przynajmniej w sklepie lub w przytykającym doń mieszkaniu i dać jej choćby znak jakiś [...], nie spodziewając się więcej nadto, iżby można parę słów z nią zamienić” (PMB 85). Nie znając rywala, męża swojej kochanki, wyobraża go sobie pod dyktando ambicji i miłości własnej raz jako „tęgiego, nieforemnego człowieka”, to znów jako „wysuszonego, ułomnego starca”. Tymczasem kramarz okazuje się mężczyzną „niezwykłego wzrostu i pięknej budowy ciała”, o obliczu „wielkiej piękności i powagi, o ciemnoblond brodzie, w której wiło się parę srebrnych nici”, o czole, które - konstatuje zaskoczony marszałek, obserwując mężczyznę z ukrycia - „tak przedziwnej było zasię wyniosłości, iż skronie większą zajmowały powierzchnię, niż kiedykolwiek zdarzyło mi się u kogo widzieć”. Nagle okazuje się, że mężczyzna ten, którego każdy gest z nieodgadnionych powodów „cechowała niesłychana nonszalancya i duma, z odcieniem prawie wzgardy” (PMB 87), przypomina Bassompierre'owi pewnego szlachetnie urodzonego więźnia, którego niegdyś trzymał pod strażą, będąc w służbie królewskiej. Bassompierre przypomina sobie także, że tamten miał zwyczaj w charakterystyczny sposób przyglądać się swojej dłoni z sygnetem, mąż kramarki tymczasem, który jest wyraźnie poruszony, mówi coś sam do siebie, zdaje się z kimś spierać, z podobną uwagą i (ponurym) skupieniem bada wygląd swoich palców i paznokci, co z kolei bezsprzecznie wskazuje na zagrożenie zarazą lub pierwsze symptomy choroby. Niejasny związek między tymi dwiema postaciami pozostaje zagadką, ale szlachecki sygnet, z którym więzień nigdy się nie rozstawal, zdaje się nawiązywać do nierozerwalności małżeństwa, którą Bassompierre właśnie naruszył, a ponure skupienie męża kramarki i nagły gest gaszenia świecy, nim zniknie z oczu podglądającego go marszałka, sugerują podjęcie jakiejś ważnej, nieodwołalnej decyzji. W finale opowieści Hofmannsthala Bassompierre dokładnie rejestruje, że jedno z nagich ciał w izbie jest „bardzo duże z nakrytą głową, drugie mniejsze, wyciągnięte tuż przy ścianie, a zaraz obok zarys jego cienia, który się wyłaniał i niknął” (PMB 91-92), co stanowi także czytelną aluzję do niedawnej sceny miłosnej z piękną kramarką: „Ostatnia głownia na kominku paliła się jaśniej, niż tamte. Sypiąc iskrami, wsysała w siebie płomień, który za chwilę strzelał wysoko, że blask uderzał na nas, jak fala rozłamująca się o ścianę, rysując na niej ostrym konturem nasze splecione cienie i znowuż je grążąc” (PMB 80).

Te mgliste wprawdzie, ale o wiele wyraźniejsze niż u Goethego aluzje do ziemskich i społecznych uwikłań bohaterów tęskniących za wyrażeniem swoich najgłębszych pragnień, czynią z przygody marszałka epizod bardziej tragiczny niż demoniczny. Wprowadzając „sobowtórną” postać kramarza, Hofmannsthal rozszerza wachlarz nasuwających się w związku z tą historią pytań (bez odpowiedzi): Jaka jest rola męża w całej tej historii? Czy kobieta była naprawdę do szaleństwa zakochana $\mathrm{w}$ znanej wszystkim osobistości, czy też może miała ukryty motyw, by mścić się na słynnym marszałku?

Pytanie zasadnicze w kontekście przeprowadzanego tu porównania jest jednak inne: czy można przyjąć, że Hofmannsthal, rozwijając niektóre wątki, pozwala lepiej ujawnić się napięciom i emocjom, tkwiącym od początku w sytuacji zarysowanej przez Bassompierre'a (autora wspomnień) i w prawie niezmienionym kształcie powtórzonej przez Goethego? 
Innymi słowy, czy Hofmannsthal stara się uczynić tę opowieść po prostu bardziej wyrazistą i przejmującą, a przez to - nie odzierając jej z tajemniczości - pragnie sprawić, by dla potencjalnych odbiorców była ona jednocześnie i bardziej pociągająca, i bardziej czytelna ${ }^{10}$ ? Czy też należy uznać, że historia Hofmannsthala ma, mimo wszelkich podobieństw fabularnych, odmienną wymowę niż ta opowiedziana przez Goethego? Aby odpowiedzieć na to pytanie, trzeba jednak wrócić do osadzenia tekstu w cyklu Gawęd niemieckich uchodźców i zastanowić się, jaką funkcję przypisywał jej Goethe.

Do pracy nad Gawędami, wzorowanymi na Dekameronie, Goethe przystąpił w 1794 roku. Zamierzał opublikować utwór w redagowanym przez Schillera czasopiśmie „Die Horen”. Jak u Boccaccia, tak i tu akcja opowieści ramowej rozgrywa się w wąskim gronie osób niejako odciętych od świata - a przynajmniej tego świata, w którym funkcjonowały dotychczas - wskutek zdarzeń nagłych, groźnych i niezależnych od ich woli ${ }^{11}$. U Goethego są to wypadki najświeższej daty, związane z wojną francusko-pruską z 1792 roku $^{12}$, a tytułowi uchodźcy chronią się po wielomiesięcznej tułaczce w majątku na wschodnim brzegu Renu. Obszerna ekspozycja rozciąga się od początku działań wojennych w Nadrenii w październiku 1792 roku po oswobodzenie Frankfurtu i oblężenie Moguncji wiosną następnego roku. Postaci, wokół których koncentruje się akcja, to: „wdowa w średnim wieku” baronessa von C., dwójka jej najstarszych, dorosłych już dzieci, Luiza i Fryderyk, kuzyn Karol - młodzieniec $w$ wieku zbliżonym do obojga rodzeństwa, pochodzący z zamożnej rodziny, dalej: nauczyciel Fryderyka oraz duchowny podeszły już w latach, nazywany w tekście często starcem - przyjaciel domu von C.

Przypomnijmy, że nie mniej rozbudowana ekspozycja Dekameronu szczegółowo przedstawia spustoszenia, jakie szerzą się we Florencji i jej okolicach wiosną 1348 roku wskutek zarazy - także i tam rama narracyjna odnosiła się zatem do wydarzeń niemal aktualnych - autentycznych wypadków ${ }^{13}$, doskonale znanych potencjalnym odbiorcom utworu. W relacji Boccaccia, operującej nad wyraz realistycznymi, a przez to wstrząsającymi scenami z życia i umierania mieszkańców miasta nawiedzonego przez nieuleczalną chorobę, wybuch i błyskawiczne rozprzestrzenianie się dżumy nie tylko pociąga sto tysięcy ofiar w ciągu niespełna pół roku, ale i burzy podstawowe zasady porządku społecznego. Upadek obycza-

10 W opublikowanym w 1908 roku eseju Balzak Hofmannsthal składa hołd nie tylko autorowi Straconych złudzeń i Kuzynki Bietki, ale i Goethemu. Za jedną z najgłębszych i najsubtelniejszych wypowiedzi Goethego uważa Hofmannsthal jego diagnozę dotyczącą odbioru własnej twórczości, gdy stwierdzał, że „jego dzieła nie są przeznaczone dla szerokiej publiczności i że prawdziwą ich treść pojmą tylko ci nieliczni, co doznali podobnych doświadczeń”. Dalej pisze Hofmannsthal: „kto na nowo zechce przyswoić sobie któreś z jego dzieł [...], ten musi przystąpić do tych książek z umysłem już oczyszczonym. Musi wyrzec się niejednego z siebie, ze swojego życia. Musi zapomnieć o wielkich miastach. Musi przeciąć tysięczne nici uczuć, myśli i chwilowych pragnień. Musi sobie przypomnieć o swoim «ciele chwalebnym», czyli o tym, co w nim jest wieczne, na wskroś człowiecze, absolutne. [...] Wtedy na pewno bez względu na to, które z dzieł Goethego kiedykolwiek otworzy, ogarnie go jednakowo wzniosła i przemieniona rzeczywistość. [...] Ale owo ramię, co unosi ku gwiazdom, nie ogarnia każdego. Podobnie za życia Goethe udzielał się tylko nielicznym, i to nie o każdej porze". H. v. Hofmannsthal, Księga przyjaciół i szkice wybrane, wybrał, przełożył i notami opatrzył P. Hertz, Kraków 1997, s. 89-90.

11 Jak zaznacza Erich Trunz w posłowiu do Gawęd, były one pod koniec XVIII wieku przedsięwzięciem całkowicie prekursorskim na gruncie niemieckim. Nie pisano tu wcześniej krótkich, nowelistycznych utworów prozą, obejmujących "całe życie” postaci, modne były obszerne powieści; również Goethe wsławiał się w takich właśnie formach, pisząc Cierpienia młodego Wertera, Wilhelma Meistra czy wkrótce potem - Powinowactwa $z$ wyboru. Por. UdA 614. Formalne nawiązanie do Dekameronu każe też spojrzeć na porewolucyjne działania wojenne przez pryzmat pierwowzoru, w którym protagoniści uciekali przed zarazą.

12 Wydarzenia wojny Francji z Austrią i Prusami w 1792 roku znane były Goethemu z autopsji.

${ }^{13}$ Chodzi o największą w dziejach Europy epidemię dżumy, która w latach 1347-1353 pochłonęła 25 milionów ofiar. 


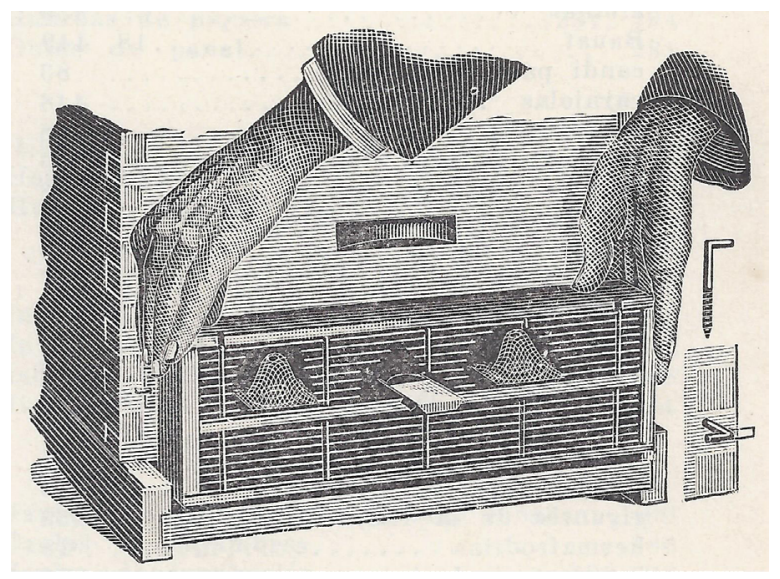

jów i zdziczenie ludzi ukazane są jako następstwa zarazy równie katastrofalne, co żniwo zbierane przez śmierć, i dlatego dziesięcioro młodych arystokratów, którzy pragną ocalić nie tylko zdrowie fizyczne, ale przede wszystkim równowagę ducha - pogodę i chęć życia, decyduje się na ucieczkę przed owym w wielorakim sensie zaraźliwym chaosem. W wiejskim majątku pod Florencją mają zaradzić mu celebrowane z taktem wspólne posiłki, spacery, rozmowy i opowieści, których treścią jest miłość.

Analogia zastosowana przez Goethego nie jest jednak mechanicznym powtórzeniem tego schematu. W Gawędach niemieckich uchodźców opowiadanie sobie historii nie jest rozrywką, zrodzoną z monotonii przeciągającej się tułaczki, ani zajęciem zastępczym, odwracającym uwagę domowników od ich niepewnej sytuacji, lecz gestem ekspiacji. Chodzi tu bowiem o wypełnienie jasno sprecyzowanego polecenia baronessy C. W obliczu narastających konfliktów i w imię wartości, które pragnie ocalić, autorytatywnie ustanawia ona swoisty regulamin dalszego funkcjonowania małej wspólnoty. Mając na uwadze oczyszczającą i formującą funkcję konwersacji, kobieta wprowadza codzienny rytuał opowiadania i słuchania historii o określonych walorach estetycznych, odznaczających się dobrym smakiem, umiarem i elegancją ${ }^{14}$, oraz wykwintnej rozmowy we własnym gronie. Powodem tej decyzji jest kłótnia, do jakiej dochodzi między porywczym Karolem a znajomym baronessy C., tajnym radcą von S., starszym panem o zdecydowanie konserwatywnych poglądach, który wraz z rodziną korzysta z gościny w majątku; dyskusja na tematy polityczne przekształca się w spór i kończy niewybrednym atakiem na sędziwego gościa. Ten, dotknięty do żywego, natychmiast porzuca ofiarowane mu schronienie i obrażony wyjeżdża wraz z całą swoją rodziną. Ów drobny z pozoru incydent jest jednak w oczach baronessy realnym i groźnym zamachem na drogi jej porządek świata, w którym takt, umiar i wzgląd na dobro innych wyznaczały nieprzekraczalne granice własnej swobody. Nie bez znaczenia jest fakt, że razem z radcą von S. wyjeżdża i jego żona, serdeczna przyjaciółka baronessy von C. z czasów młodości, co dodatkowo rani obie kobiety. I jak u Boccaccia właśnie kobiety - wykształcone i szanowane - dają impuls do oderwania się od z a r a ż o n e go świata, tak i u Goethego inicjatywę przejmuje energiczna kobieta, rozdrażniona skutkami niepotrzebnej zwady. Naj-

14 Jako swoistą autoironię ze strony Goethego można rozumieć żą danie baronessy, by w żadnym razie nie były to opowiadania z ramą. 
pierw samorzutnie odnajduje się w roli przywódcy grupki znękanych uchodźców, gdy podtrzymuje innych na duchu, dodaje im odwagi i troszczy się o nich, potem, gdy postanawia bronić miru domowego na przekór wszystkiemu. Baronessa C. nie ma zamiaru akceptować w swoim otoczeniu nowomodnej nonszalancji, braku szacunku dla obyczajów uświęconych tradycją i dobrych manier, ponieważ to one gwarantują zbawienny ład w społecznej mikroskali, to znaczy w indywidualnych kontaktach międzyludzkich; ład, którego pochodna w skali kraju jest właśnie niszczona w zawierusze przemocy - rewolucji ${ }^{15} \mathrm{i}$ wojny.

Sztuka pięknego opowiadania i pięknej rozmowy jako wyraz piękna duchowego będzie odtąd lekarstwem na grożący chaos. Erich Trunz podsumowuje to w swoim posłowiu następująco:

Słowa baronessy - „niechże chociaż forma świadczy o tym, że znajdujemy się w dobrym towarzystwie" - dowodzą, że jasna jest zależność między opowieścią a społecznością. [...] Baronessa i duchowny przenoszą nas w klarowny klimat osiemnastowiecznej konwersacji; ironia i intelektualna lekkość z góry wykluczają branie czegoś przesadnie na serio. Mistrzostwo formy wiąże się z charakterem i wykształceniem opowiadającego, z rozległą perspektywą jego spojrzenia na życie i człowieka. [UdA 614]

Główną rolę odegra tu duchowny: jego gawędy, zapowiadane wprawdzie jako „coś lekkiego na deser”, jako opowieści o „odczuciach, które mężów i niewiasty połączyły bądź podzieliły, uczyniły szczęśliwymi lub wtrąciły w rozpacz, częściej jednak mąciły rozeznanie niźli objaśniały" (UdA 143), okażą się konstrukcjami o jasnym przesłaniu moralnym, którego fundamentem jest opanowanie i umiar, wierność i poznanie samego siebie. I tylko pierwszy wieczór, zanim na dobre głos zabierze duszpasterz, należy jeszcze do młodzieży oraz przyprawiających o dreszcz historii poświęconych zjawiskom intrygującym i niewyjaśnionym. Jako trzecia z kolei zaprezentowana zostaje tu właśnie przygoda marszałka de Bassompierre - co ciekawe, historię tajemniczego romansu arystokraty z ponętną kramarką opowiada wcielający się w rolę samego narratora Karol, zuchwały, ale i skruszony już młodzieniec.

Skoro więc Hofmannsthal zmienia narracyjne otoczenie opowieści i pozbawia ją całego tego dydaktycznego kontekstu, w jaki wyposażył ją jego poprzednik, Przygoda marszałka de Bassompierre staje się utworem o zupełnie innym przesłaniu. O ile Goethe pod wpływem rewolucji francuskiej i wojen napoleońskich zwraca się w latach dziewięćdziesiątych XVIII wieku ku idei ładu i powściągliwości, czego wyrazem jest m.in. zamysł zrealizowany w Gawędach niemieckich uchodźców, o tyle Hofmannsthal - „cudowne dziecko” wiedeńskiej moderny - hołdując odmiennym upodobaniom estetycznym, pławi się w świecie pomieszanych wartości przełomu wieków, w którym z jednej strony najwyżej ceniona jest indywidualność, z drugiej - kwestionowane istnienie suwerennego Ja. Potwierdza to również kompozycja książkowego wydania jego wersji przygody; prócz niej na tom złożyły się: Baśń 672. nocy, Powieść o jeźdźcu oraz List - teksty, dla których, zdaniem wytrawnego znawcy literatury przełomu wieków Gottharta Wunberga, schizofreniczna wizja rzeczywistości

15 Nie przypadkiem w punkcie kulminacyjnym kłótni między Karolem a radcą von S. ze strony zapalczywego młodzieńca pada życzenie, by i w Niemczech gilotyna zebrała wreszcie należne jej żniwo, por. UdA 133. 
jest podstawową, konstytuującą zasadą ${ }^{16}$. W istocie zarówno Baśń 672. nocy, jak i Powieść o jeźdźcu łączy z Przygoda marszatka de Basompierre niewytłumaczalność opisywanych zdarzeń, gęsta atmosfera irracjonalnych związków między sobowtórnymi postaciami, pojawiającymi się znienacka, znaczącymi coś, co nie daje się odgadnąć. W Baśni przeważa klimat chorobliwej wręcz melancholii, poczucie osaczenia i stopniowej dystrofii zdezorientowanego Ja, w Powieści o jeźdźcu - pozorna beztroska, wręcz dezynwoltura protagonisty, zderzona z krwawą rzeczywistością działań wojennych i zaskakującym finałem. Z kolei List - bardziej znany pod tytułem List lorda Chandosa - uznany za epokowy manifest sceptycyzmu wobec języka jako środka wyrazu i komunikacji, w pierwszym wydaniu polskim z roku 1919 nie bez racji określany jest ${ }^{17}$ jako tekst „mistrzowsko, z ogromną subtelnością kreślący chorobę intelektu, chwianie się pojęć, patologiczne stadyum świadomości, rozrosłej ponad miarę” (PMB 17). Nadając swojej wersji przygody tragiczny rys, Hofmannsthal uwspółcześnia ją. Mimo że ogromnie ceni dokonania Goethego, posługując się tekstem swego wielkiego poprzednika, podejmuje $\mathrm{z}$ nim swoistą polemikę. W konfrontacji dwu wizji świata reprezentowanych przez Goethego i Hofmannsthala z jednej strony dochodzi do głosu afirmatywny stosunek do umiaru i samoograniczenia, a z drugiej estetyzująca wizja nieokiełznanych namiętności i ekstremalnych doznań. Wiara Goethego w sens ładu i tego ładu pochwała nie wynikają z nieświadomości czyhającego podskórnie chaosu, wręcz przeciwnie, tyle że w jego wersji demoniczność uzyskuję dzięki opowieści ramowej jasną przeciwwagę, której całkowicie brak już u Hofmannsthala. Napięcie między obu wersjami zachowuje swoją dramatyczność do dziś, czyniąc z przygody marszałka de Bassompierre opowieść w jakiś sposób ponadczasową, właśnie dzięki rozbieżności znaczeń realizujących się w jednym i drugim literackim opracowaniu.

\section{Bibliografia}

Goethe Johann Wolfgang, Unterhaltungen deutscher Ausgewanderten, [w:] idem, Werke. Hamburger Ausgabe, t. 6: Romane und Novellen I, München: Deutscher Taschenbuch Verlag, 1981.

Hofmannsthal Hugo von, Księga przyjaciót i szkice wybrane, wybrał, przełożył i notami opatrzył Paweł Hertz, Kraków: Wydawnictwo Literackie, 1997.

— Przygoda marszatka de Bassompierre, przeł. Ida Wieniewska, Lwów: Wydawnictwo Polskie, 1919.

Kovács László, Grenzüberschreitungen: Goethes Bassompierre-Novelle, http://epa.oszk. $\mathrm{hu} / 02100 / 02137 / 00018 / \mathrm{pdf} / \mathrm{EPA02137}$ _ISSN_1219-543X_tomus_14_fas_3_2009_ ger_161-166.pdf (dostęp: 24.09.2015).

Kraft Werner, Das Erlebnis des Marschalls von Bassompierre, [w: ] Hugo von Hofmannsthal, red. Sibylle Bauer, Darmstadt: Wissenschaftliche Buchgesellschaft, 1968.

Szcześniak Dorota, Z mitości do stowa (Hugo von Hofmannsthal, „Księga przyjaciót”), [w:] Arcydzieła literatury niemieckojęzycznej. Szkice, komentarze, interpretacje, red. Edward Białek i Grzegorz Kowal, Wrocław: Wrocławskie Wydawnictwo Oświatowe, 2011.

Wunberg Gotthart, Der frühe Hofmannsthal. Schizophrenie dichterische Struktur, Stuttgart-Berlin-Köln-Mainz: Kohlhammer, 1965. 1965.

${ }^{16}$ G. Wunberg, Der frühe Hofmannsthal. Schizophrenie dichterische Struktur, Stuttgart-Berlin-Köln-Mainz

17 Tekst przedmowy pochodzi zapewne od tłumaczki Idy Wieniewskiej, brak bowiem oddzielnej adnotacji o autorze. 